\title{
Infusing Islamic-related content through Trivia Cards: Research \& development in ESP classroom
}

\author{
Rafika Rabba Farah \\ English Language Education Department, Universitas Muhammadiyah Malang, \\ Indonesia \\ Corresponding Author \\ Email: rafikafarah@gmail.com
}

\begin{abstract}
English learning has now largely been driven by global socioeconomics. Thus, English for Specific Purposes is likely taught at tertiary level education in Asia. Especially, in Indonesia, where Muslim is the major population, teaching English to students majoring in Islamic Studies must be carefully planned. Experts have discussed widely that English language has its association to Western civilization and Christian value. Therefore, this present research aims at developing Trivia Cards which infuse Islamic elements to teach English for Islamic Studies for students majoring in Islamic discipline at one private Islamic university in Indonesia. Research and Development (R\&D) was implemented in the study involving some procedures as follows: need analysis, product design, product validation, and revision. Results on need analysis comprised five important topics, they were Islamic manner (akhlak), oneness of God (tauhid), Islamic history, and hadith. Further, the experts highlighted that the media developed reached its validity criteria as it was scored $98.07 \%$ by media-language expert; and scored $88.6 \%$ by content expert. Furthermore, the study were 95\% positively responded by the respondents with $45 \%$ strongly agreed and $50 \%$ agreed respectively; meanwhile only small portion stated his/her disagreement for $5 \%$ or as many of one respondent. Thus, this study has shed a light that Islamic content can provide a way for English teachers to teach English to students with Muslim background.
\end{abstract}

Keywords: English for Islamic Studies; Trivia Cards; Research and Development

Received: $\quad$ Revised:

18 November 20194 February 2020
Accepted:

6 February 2020
Published:

29 February 2020

\section{INTRODUCTION ESP and its practice}

Designing a curriculum which is lenient to learners' need and interest in Indonesia is in a high demand. Highlighting the issue of internationalization, in particular with ASEAN economic community and ASEAN Free Trade Area in the national context, the need of English mastery has shifted away. Today, the new job market requires learners to be skilful in specific occupational skills. Importantly, the idea of mastering a specialized form of English is now required in many sectors. English has been used widely in different situations 
Farah, R.R.(2020). Infusing Islamic-related content through Trivia Cards: Research \& development in ESP classroom. EduLite: Journal of English Education, Literature, and Culture, 5 (1), 78-88. DOI: http://dx.doi.org/10.30659/e.5.1.78-88

and purposes. As a result, English teaching curriculum should have a move changing its general English curriculum into a more subject-specific curriculum. A specialized form of English can open up opportunities for learners to continue learning and adapting in international working life.

In this nuance, at tertiary level, designing a specific English program such as English for Specific Purposes (ESP) provides as a bridging program set for freshmen at their first year of university. More or less the idea of ESP is an attempt of integrating content and language (English) in one go. Through this model, the non-English major learners can be equipped with more exposure to English convention in their classes. However, the implementation of ESP in tertiary level can be problematic as it challenges teachers' identity-ESP teachers are no more as the primary source of knowledge (Farah, 2018).

In this regards, to elicit the problem, ESP teachers need to equip themselves with creativity, one of the ways is through developing media for teaching. In this research, English learning for Islamic Studies learners is projected. Following the idea, thus, Islamic content will be taught in English.

\section{Media for English teaching}

The implementation of ESP however is likely linked to the teaching of units of language skills. One of the language skills taught is speaking. In speaking class, activities are directed that students will be equipped with professional and academic purposes. Concerning on the need of students in Islamic Studies, students' needs for speaking is important as their output will be teachers, attorney, and judge. Thus, the idea of focusing on developing their oral needs more attention (Paltridge $\&$ Starfield, 2013). In speaking class, the focus of learning is no more on forms but on language fluency and accuracy.

Teaching oral skills can be performed by considering on some important aspects. In speaking class, students need more opportunities for oral production, thus, teachers are encouraged to create meaningful activities which lead students to have learning opportunities. In ESL context, this opportunity can be mediated through games and sequenced task so that students will have a chance to read, listen, then talk to their peers. To accomplish this objective, oral skill is often facilitated by printed media such as poster, chart, model, image, and card.

Visual aids have indeed helpful for learning. Macwan (2015) has researched on the use of visual aids and the result shows its positive effect on building students' imagination which lead to critical thinking, debates, and group discussion. Likewise, learning through flash cards has also improved students' vocabulary (Nugroho, Nurkamto, \& Sulistyowati, 2012). Furthermore, Sholichah (2016) has developed cards for vocabulary learning and reached its validity as it scored 47 from media expert; 51 from content expert; 88,5 from peer review; 98,67 from English teachers; 62,27 from students' response.

\section{ELT in Muslim context}

However, the notion of teaching English in Muslim context is not easy for two main circumstances. First, the conception of teaching a language that must go hand in hand with its culture has become the common sense of how a 
language should be taught to foreign learners. Language and culture are believed to be strictly tight as Kramsch (2013) states that culture in language learning give understanding of a context, thus, meaning-making is easy to gain. Meanwhile, English and Islamic worldview have been widely discussed of having a clash of civilization-different norm or value between Western and Islam do exist (Ahmad, Abdullah, Ghani \& Faizal, 2014).

Previous researchers who really are concerned on how English should be taught in Muslim populated country note two important concerns. The first is to maintain the Islamic value. As stated by Mohd-Asraf (2005), "English is more than just a language; Islam is more than just a religion." In addition, Karmani (2005) also pinpoints the same notion that teaching English is a way to make, "More English and less Islam." In this regards, the idea of infusing Islamic-related content to students with Islamic background is paramount. Thus, supporting teachers with media to teach English for Islamic Studies serves as a way out to this stern issue.

Negative attitudes and motivations towards English learning has been highlighted in some researches. For instance, Abidin, Pour-Mohammadi and Alzwari (2012) on their study on cognitive, behavioural, and emotional aspects on students in Libya reveal that the students were found to have negative attitudes towards English learning. In addition, Ahmed (2015) finds that students in Malaysia were generally positive in attitudes, however, most students had negative attitudes or fear towards classroom instruction. Furthermore, some Malaysian students also believe that English has association to non-Muslim language (kafir) and colonialization (Ahmad et al, 2014). In Pakistani context, some students from the Faculty of Islamic Studies were positive towards Western culture which discusses on social organization but not on cultural entities (Jabeen \& Shah, 2011).

In addition, a preliminary research conducted by Farah and Sumarsono (2019) measuring the needs of Faculty Islamic Studies students in speaking course highlights on the importance of integrating speaking skills taken place in formal setting in English for Academic Purposes with some mixtures to materials for General English.

However, of the previously mentioned issue, there are still fairly limited studies which are trying to address the phenomena by developing English Muslim friendly curriculum. Thus, in this present research, the researcher has an attempt to develop English curriculum that infuse Islamic elements in the learning. In this notion, the idea of developing Trivia Cards English for Islamic Studies has been thoughtfully designed aiming at measuring how the Trivia Card for English for Islamic Studies is developed.

Trivia is known as a game where students has to compete with the other group of students using cards. The trivia card in this research is designed for speaking class. The cards will detail some questions about Islamic knowledge, such as about Qur'an, hadith, five pillars of Islam, dua, the prophets, the angels, and so forth. The cards will be projected in two games; playing and saying. The 'playing cards' require students to act upon the question mentioned in the cards; while the 'saying cards' ask students to answer the question. The research problems of this research are formulated to measure the validity of English for Islamic Studies Trivia Cards used to teach speaking. 
Farah, R.R.(2020). Infusing Islamic-related content through Trivia Cards: Research $\&$ development in ESP classroom. EduLite: Journal of English Education, Literature, and Culture, 5 (1), 78-88.

DOI: http://dx.doi.org/10.30659/e.5.1.78-88

\section{METHOD}

This research implemented Research and Development (R\&D) model based on Dick, Carey, and Carey (2015). This model aims at developing a new product of media to learn English in the context of Islamic Studies. Adopting Dick, Carey, and Carey (2015), some procedures had been taken in this research, they were: Need Analysis (NA), initial product design, expert validation (medialanguage expert and content expert), trial phase, and finally product revision. One media-language expert was a lecturer who had expertise in the field based in English Language Education Department whereas one content expert was a lecturer from Islamic Education Department at the same university. The research subject were students of Islamic Law (Sharia) who were at the time frame taking ESP program as their compulsory course at one of private Islamic-affiliated universities in Indonesia.

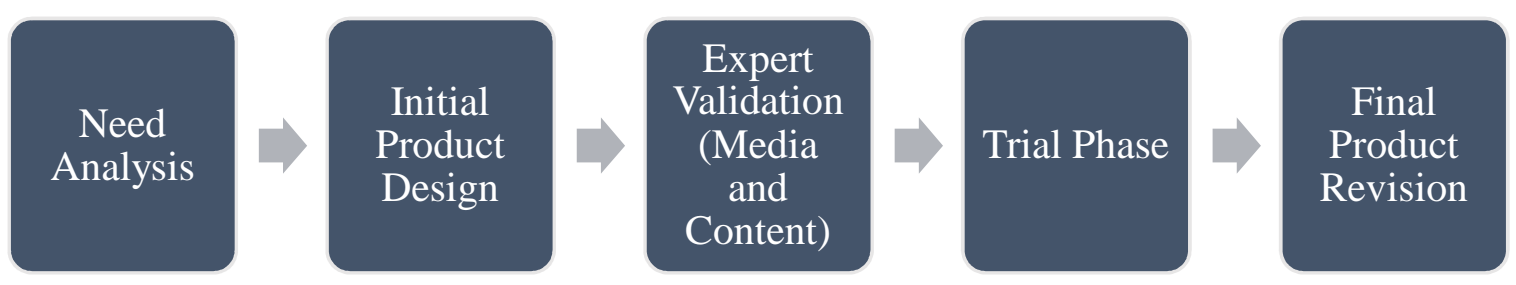

Figure 1. The flow chart of research procedure (adapted from Dick, Carey, Carey, 2015)

\section{RESULTS AND DISCUSSION}

The research findings are consecutively summarized based on the results of need analysis, product design, expert validation, and product testing which later verified based on validity criteria.

\section{Need Analysis}

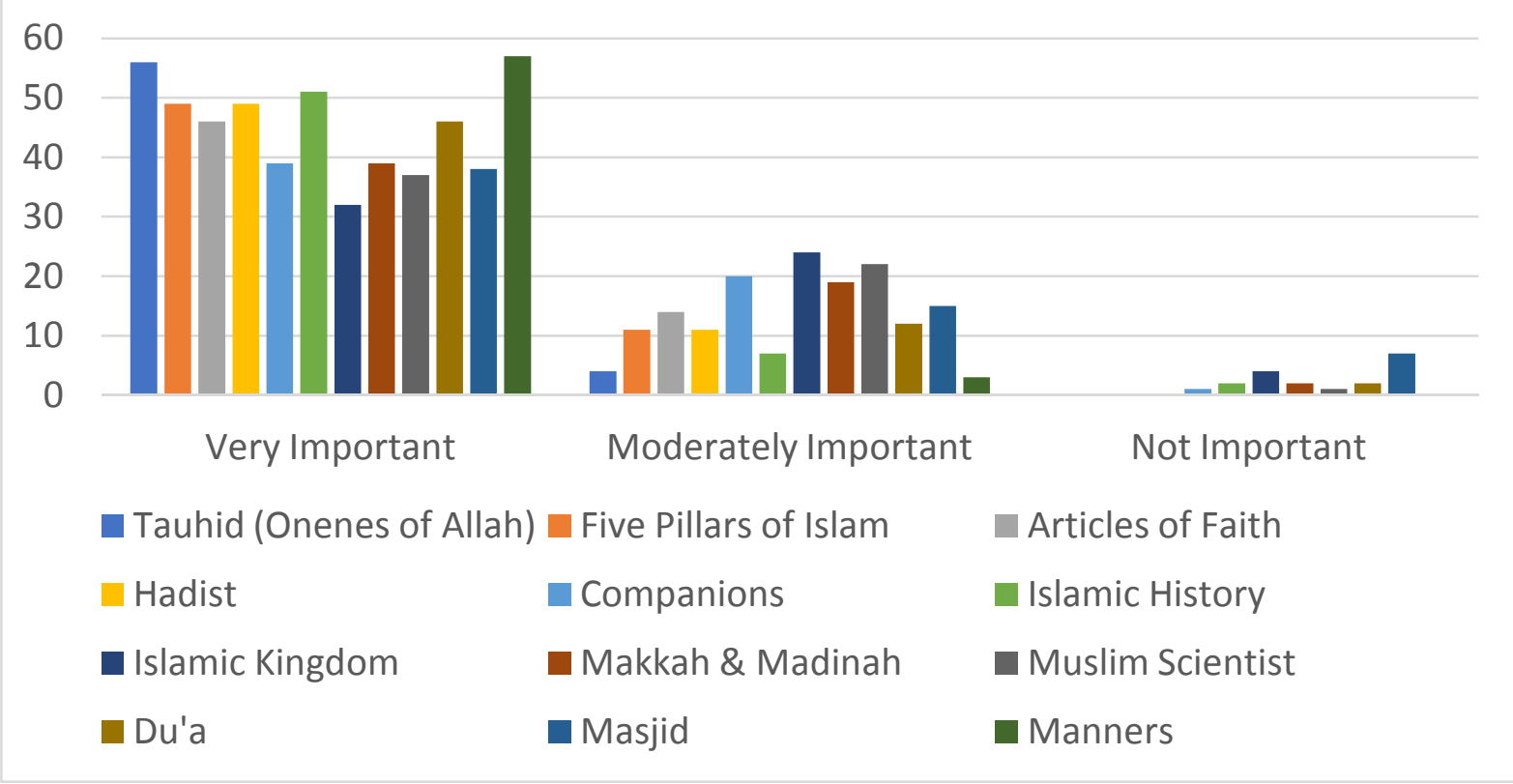

Figure 2. Results of need analysis highlighting on 12 topics of Islamic studies content 
EduLite Journal of English Education, Literature, and Culture Vol. 5, No. 1, February 2020, pp. 78-88

E-ISSN: 2528-4479, P-ISSN: 2477-5304 http://jurnal.unissula.ac.id/index.php/edulite DOI: http://dx.doi.org/10.30659/e.5.1. 78-88

Among the 12 preferred topics chosen by respondents, the 5 top list were selected as topics for trivia card concept. They were about: Islamic manner (akhlak) $(\mathrm{n}=57)$, Oneness (tauhid) $(\mathrm{n}=56)$, Islamic History $(\mathrm{n}=51)$, Five Pillars of Islam $(n=49)$, and Hadith $(n=49)$.

\section{Product design}

In each topic among the five highest topics chosen, the trivia cards are developed into 25 cards, thus, they make 100 cards in total.

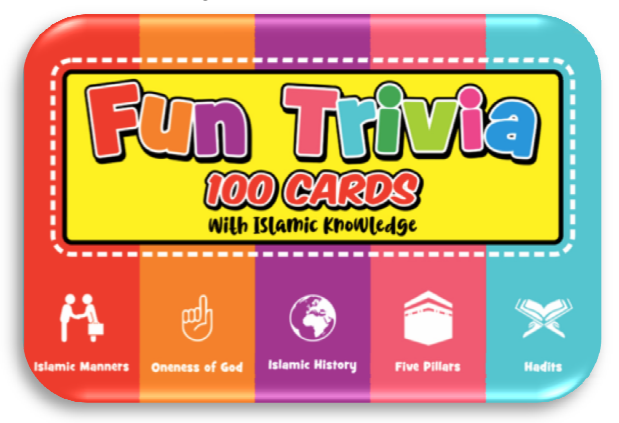

Figure 3. The front side of the trivia cards

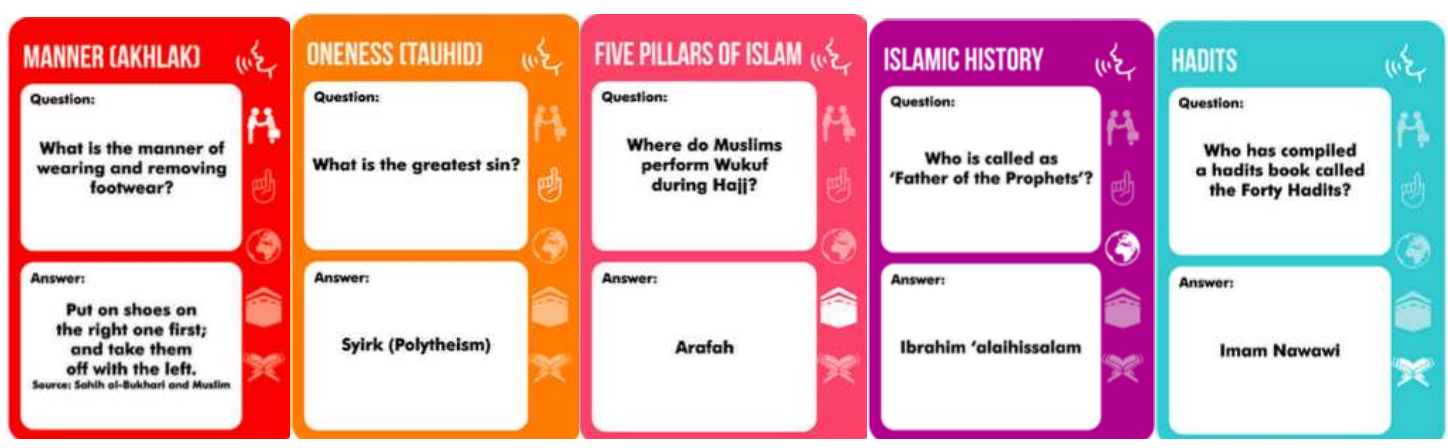

Figure 4. The 'saying cards' of the trivia cards

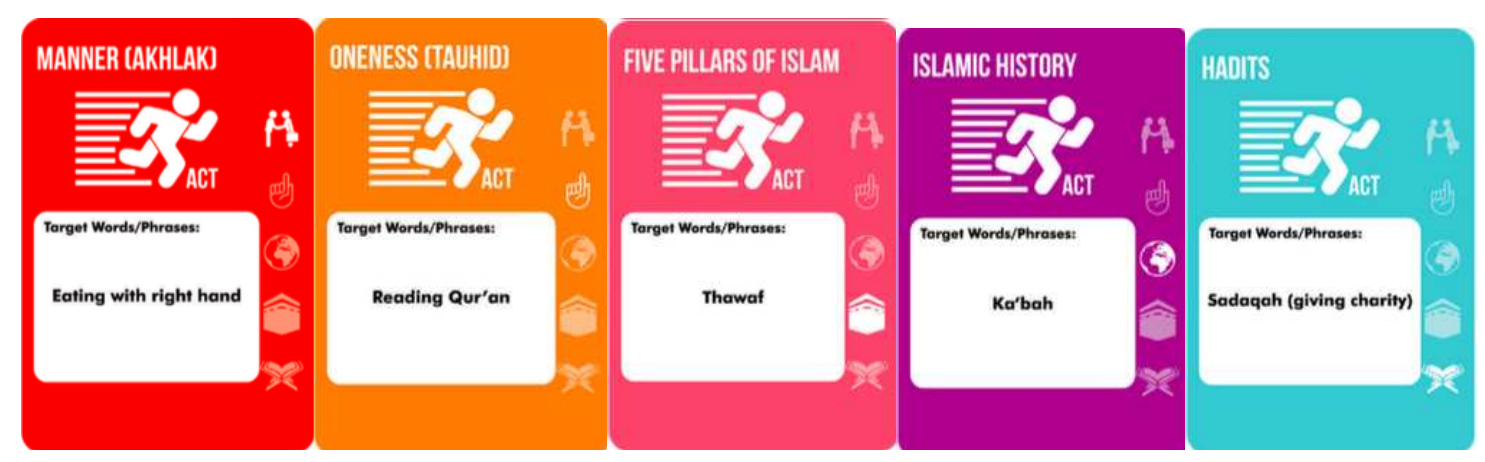

Figure 5. The 'acting cards' of the trivia cards

After been developed, the trivia cards with Islamic content were validated by one media-language expert and one content expert. Afterwards, the trivia cards were implemented in Islamic Law class, then students were asked their opinion towards the cards. Here are the results of the research: 
Farah, R.R.(2020). Infusing Islamic-related content through Trivia Cards: Research \& development in ESP classroom. EduLite: Journal of English Education, Literature, and Culture, 5 (1), 78-88.

\section{Media-language expert profile:}

Laela Hikmah Nurbatra, M.A.,M.EdLead.

A lecturer at English Department University of Muhammadiyah Malang Master from University of New South Wales

Has been teaching Media and Source of Learning for at least 4 years

Coordinator of English Language Media Expo for consecutively 2 years

\begin{tabular}{|c|c|c|c|c|c|c|}
\hline \multicolumn{7}{|c|}{ Media-language Expert Judgment } \\
\hline No. & Aspect & Criteria & 1 & 2 & 3 & 4 \\
\hline \multirow[t]{3}{*}{1} & \multirow[t]{3}{*}{ Practicality } & Easy to use in the classroom & & & & $\sqrt{ }$ \\
\hline & & Easy to carry & & & & $\sqrt{ }$ \\
\hline & & Support independent learning & & & $\sqrt{ }$ & \\
\hline \multirow[t]{5}{*}{2} & \multirow[t]{5}{*}{ Appearance } & Desion & & & & $\sqrt{ }$ \\
\hline & & Card size & & & & $\sqrt{ }$ \\
\hline & & Writing and readability & & & & $\sqrt{ }$ \\
\hline & & Image & & & & $\sqrt{ }$ \\
\hline & & Color & & & & $\sqrt{ }$ \\
\hline \multirow[t]{5}{*}{3} & \multirow[t]{5}{*}{ Language } & Correct terminology & & & & $\sqrt{ }$ \\
\hline & & Correct structure & & & & $\sqrt{ }$ \\
\hline & & Sentence effectiveness & & & & $\sqrt{ }$ \\
\hline & & Correct spelling & & & & $\sqrt{ }$ \\
\hline & & Correct symbol & & & & $\sqrt{ }$ \\
\hline
\end{tabular}

Notes: 1 = Poor, 2 = Fair, 3 = Good, 4 = Excellent

Total of Score $\quad=4$ (scales) $\times 13$ (items) $=52$

Score Derived $\quad=51$ (score achieved) $/ 52$ (total score) $\times 100 \%=98.07$

\section{Content Expert Profile:}

Saiful Amien, M.Pd.

A senior lecturer at Faculty of Islamic Studies

A Doctor Candidate at State University of Malang

Majoring in Educational Technology

Has developed teaching source for Arabic learning

Graduated from Islamic College Gontor 
EduLite Journal of English Education, Literature, and Culture Vol. 5, No. 1, February 2020, pp. 78-88

Table 1. Content expert judgment

\begin{tabular}{|c|c|c|c|c|c|}
\hline No & Aspects & Criteria & 1 & 3 & 4 \\
\hline \multirow{6}{*}{1} & \multirow{6}{*}{$\begin{array}{l}\text { Materials / Conte } \\
\text { nt }\end{array}$} & $\begin{array}{l}\text { Materials/topics are in line with students' } \\
\text { discipline }\end{array}$ & & & $\sqrt{ }$ \\
\hline & & Concept and definition are correct & & $\sqrt{ }$ & \\
\hline & & Terminology used is correct & & $\sqrt{ }$ & \\
\hline & & $\begin{array}{l}\text { Materials and students' competence are } \\
\text { match }\end{array}$ & & & $\sqrt{ }$ \\
\hline & & Pictures and symbols are accurate & & $\sqrt{ }$ & \\
\hline & & $\begin{array}{l}\text { Materials are encouraging students to have } \\
\text { them practiced into their daily life }\end{array}$ & & $\sqrt{ }$ & \\
\hline \multirow{5}{*}{2} & \multirow{5}{*}{$\begin{array}{l}\text { Teaching and } \\
\text { Learning }\end{array}$} & $\begin{array}{l}\text { Invites students to study Islam and English at } \\
\text { one go }\end{array}$ & & $\sqrt{ }$ & \\
\hline & & Encourages students to ask questions & & & $\sqrt{ }$ \\
\hline & & Motivate students to learn & & $\sqrt{ }$ & \\
\hline & & Creates student-centred learning & & & $\sqrt{ }$ \\
\hline & & Encourage students' interaction & & & $\sqrt{ }$ \\
\hline
\end{tabular}

Notes: $1=$ Poor, 2 = Fair, 3 = Good, 4 = Excellent

Total of Score $=4$ (scales) $\times 11$ (items) = 44

Score Derived $=38($ score achieved) $/ 44($ total score) $\times 100 \% \quad=86.3$

\section{Product testing}

Students' response

Upon the implementation of the product in the classroom, a number of 22 students were asked for their response. Here is the detail of students' response:

Table 2. Students' response

\begin{tabular}{|c|c|c|c|c|c|c|c|c|c|c|c|c|c|}
\hline \multirow{2}{*}{$\begin{array}{c}\text { Res } \\
\text { pon } \\
\text { den } \\
t\end{array}$} & \multicolumn{10}{|c|}{ Statements } & \multirow[t]{2}{*}{$\begin{array}{c}\text { Tot } \\
\text { al }\end{array}$} & \multirow[t]{2}{*}{$\begin{array}{l}\text { Aver } \\
\text { age }\end{array}$} & \multirow{2}{*}{$\begin{array}{c}\text { Cat } \\
\text { egor } \\
\mathrm{y}\end{array}$} \\
\hline & $\mathrm{X} 1.1$ & $\mathrm{X} 1.2$ & $\mathrm{X} 1.3$ & $\mathrm{X} 1.4$ & $\mathrm{X} 1.5$ & $\mathrm{X} 1.6$ & $\mathrm{X} 1.7$ & $\mathrm{X} 1.8$ & $\mathrm{X} 1.9$ & $\begin{array}{c}\mathrm{X} 1.1 \\
0\end{array}$ & & & \\
\hline 1 & 1 & 1 & 1 & 1 & 1 & 1 & 1 & 1 & 1 & 1 & 10 & 1 & $\mathrm{SA}$ \\
\hline 2 & 1 & 1 & 1 & 1 & 1 & 1 & 1 & 1 & 1 & 1 & 10 & 1 & SA \\
\hline 3 & 3 & 4 & 2 & 2 & 2 & 3 & 3 & 2 & 2 & 2 & 25 & 2.5 & $\mathrm{D}$ \\
\hline 4 & 2 & 2 & 2 & 2 & 2 & 2 & 2 & 2 & 2 & 2 & 20 & 2 & A \\
\hline 5 & 2 & 2 & 2 & 2 & 2 & 2 & 2 & 2 & 2 & 2 & 20 & 2 & A \\
\hline 6 & 2 & 2 & 2 & 2 & 2 & 2 & 2 & 2 & 2 & 2 & 20 & 2 & A \\
\hline 7 & 2 & 2 & 2 & 1 & 1 & 2 & 2 & 1 & 1 & 2 & 16 & 1.6 & A \\
\hline
\end{tabular}


Farah, R.R.(2020). Infusing Islamic-related content through Trivia Cards: Research \& development in ESP classroom. EduLite: Journal of English Education, Literature, and Culture, 5 (1), 78-88.

DOI: http://dx.doi.org/10.30659/e.5.1.78-88

\begin{tabular}{cccccccccccccc}
\hline 8 & 2 & 2 & 2 & 2 & 1 & 3 & 2 & 1 & 3 & 1 & 19 & 1.9 & $\mathrm{~A}$ \\
\hline 9 & 2 & 2 & 2 & 1 & 1 & 1 & 2 & 1 & 2 & 2 & 16 & 1.6 & $\mathrm{~A}$ \\
\hline 10 & 1 & 1 & 1 & 1 & 1 & 2 & 1 & 1 & 2 & 1 & 12 & 1.2 & $\mathrm{SA}$ \\
\hline 11 & 2 & 1 & 1 & 2 & 2 & 2 & 1 & 1 & 2 & 2 & 16 & 1.6 & $\mathrm{~A}$ \\
\hline 12 & 1 & 1 & 2 & 1 & 2 & 2 & 1 & 2 & 2 & 1 & 15 & 1.5 & $\mathrm{SA}$ \\
\hline 13 & 1 & 2 & 1 & 2 & 2 & 2 & 2 & 1 & 2 & 1 & 16 & 1.6 & $\mathrm{~A}$ \\
\hline 14 & 1 & 2 & 2 & 2 & 2 & 2 & 2 & 2 & 2 & 2 & 19 & 1.9 & $\mathrm{~A}$ \\
\hline 15 & 1 & 1 & 1 & 1 & 1 & 1 & 1 & 1 & 1 & 1 & 10 & 1 & $\mathrm{SA}$ \\
\hline 16 & 1 & 1 & 1 & 1 & 1 & 1 & 1 & 1 & 1 & 1 & 10 & 1 & $\mathrm{SA}$ \\
\hline 17 & 1 & 1 & 1 & 1 & 1 & 1 & 1 & 1 & 1 & 1 & 10 & 1 & $\mathrm{SA}$ \\
\hline 18 & 1 & 1 & 1 & 1 & 1 & 1 & 1 & 1 & 1 & 1 & 10 & 1 & $\mathrm{SA}$ \\
\hline 19 & 1 & 1 & 1 & 1 & 1 & 1 & 1 & 1 & 1 & 1 & 10 & 1 & $\mathrm{SA}$ \\
\hline 20 & 1 & 1 & 1 & 1 & 1 & 1 & 1 & 1 & 2 & 1 & 11 & 1.1 & $\mathrm{SA}$ \\
\hline 21 & 1 & 1 & 1 & 2 & 2 & 1 & 2 & 1 & 2 & 2 & 15 & 1.5 & $\mathrm{~A}$ \\
\hline 22 & 1 & 2 & 2 & 1 & 1 & 2 & 2 & 1 & 2 & 2 & 16 & 1.6 & $\mathrm{~A}$ \\
\hline 1
\end{tabular}

1= Strongly Agree (SA); 2=Agree (A); 3=Disagree (D); 4=Strongly Disagree (SD)

$\begin{array}{lll}\text { The highest } & : 10 \times 4 & =40 \\ \text { The lowest } & : 10 \times 1 & =10 \\ \mathrm{Xi} & : 1 / 2(40+10) & =25 \\ \mathrm{Sbi} & : 1 / 6(40-10) & =5\end{array}$

$\mathrm{X}<20 \quad$ : Strongly Agree

$20>\mathrm{X}>25 \quad$ : Agree

$25>\mathrm{X}>30 \quad$ : Disagree

$\mathrm{X}>30 \quad$ : Strongly Disagree

The media were positively responded as there were $45 \% \quad(n=10)$ respondents recorded to strongly agreed on the media; $50 \%(n=11)$ agreed; while only small portion stated his/her disagreement for $5 \%(=1)$.

Table 3. Percentage of Validity Criteria

\begin{tabular}{|c|c|}
\hline Score $\%$ & Category \\
\hline $81 \%-100 \%$ & Very Good \\
\hline $61 \%-80 \%$ & Good \\
\hline $41 \%-60 \%$ & Fair \\
\hline $21 \%-40 \%$ & Poor \\
\hline$<20 \%$ & Very Poor \\
\hline
\end{tabular}

(Adapted from Kurniaman \& Zufriady, 2019)

\section{Discussion}

This present research has supported the idea that has been highlighted by Mohd-Asraf (2005) previously that ELT in Muslim context should maintain the Islamic value. Also, this media development has reinforced Karmani's (2005) idea about ELT in Muslims setting must translate their own purpose of teaching and learning. In such doing, the trivia cards with Islamic content developed in this study is appropriate to be used in ELT with Muslim background, thus, infusing them with more Islamic-friendly curriculum. 
Furthermore, the effort done in this research is projected to eliminate the Muslim students' resistance to learn English as having association to colonialism, the language of others, cultural clash to students' identity which lead to their negative attitude of their English learning (Abidin et al, 2012; Ahmed, 2015; Jabeen \& Shah, 2011). Students' problem in regards to motivation in learning English must be addressed, otherwise, their opposition towards language cultural entities will be rooted that in long term will affect their success of learning.

In regards to this, the attempt of developing Islamic-content material in English classroom has in fact been positively responded by the students as the users of the media. Also, the media-language expert as well as the content expert have their positive responses towards this effort. In the future, the opportunity to such doing is widely opened for teachers and curriculum developers. Putting students' background into consideration will give many advantages toward English learning, particularly ELT in Muslim context.

\section{CONCLUSION}

Results show that, in its validity, the experts highlighted that the media developed reached its appropriateness as it was scored $98.07 \%$ by medialanguage expert; and scored $88.6 \%$ by content expert. Furthermore, according to users' response (students), the trivia cards developed were responded positively as the overall score was $95 \%$ with $45 \%$ strongly agreed and $50 \%$ agreed respectively, only $5 \%$ conveyed his/her disagreement. Referring to its validity criteria, the media is considered as "Very Good" media. In short, this media is eligible to be implemented in ELT classroom where the Muslim learners serve as the target learners.

\section{ACKNOWLEDGEMENT}

The researcher would like to convey her gratitude as this research is fully funded by the Blockgrant of Faculty of Teacher Training and Education University of Muhammadiyah Malang, Indonesia.

\section{REFERENCES}

Abidin, M. J. Z., Pour-Mohammadi, M., \& Alzwari, H. (2012). EFL students' attitudes towards learning English language: The case of Libyan secondary school students. Asian social science, 8(2), 119.

Ahmad, I. S., Abdullah, H., Ghani, A., \& Faizal, M. (2014). Attitudes and motivation toward learning the English language among students from Islamic education system background: Exploring the views of teachers. Journal of Education and learning, 8(3), 195-208.

Ahmed, S. (2015). Attitudes towards English Language Learning among EFL Learners at UMSKAL. Journal of education and practice, 6(18), 6-16.

Dick, Walter., Carey, Lou., Carey, James O. 2015. The Systematic Design of Instruction Eight Edition. The United States of America: Pearson 
Farah, R.R.(2020). Infusing Islamic-related content through Trivia Cards: Research $\&$ development in ESP classroom. EduLite: Journal of English Education, Literature, and Culture, 5 (1), 78-88.

Farah, R. R. (2018). 'Who am I? 'Interrogating my identity as ESP teacher: Personal narration. Celtic: A Journal of Culture, English Language Teaching, Literature, \& Linguistics, 3(1), 1-14.

Farah, R. R., \& Sumarsono, P. The English needs of Islamic Studies learners: ESP speaking course model. In 6th International Conference on Community Development (ICCD 2019). Atlantis Press.

Jabeen, F., \& Shah, S. K. (2011). The role of culture in ELT: Learners' attitude towards the teaching of target language culture. European Journal of Social Sciences, 23(4), 604-613.

Karmani, S. (2005). Petro-linguistics: The emerging nexus between oil, English, and Islam. Journal of language, Identity, and Education, 4(2), 87102.

Kramsch, Claire. 2013. Culture in foreign language teaching. Iranian Journal of Language Teaching Research 1, no. 1 (2013): 57-78.

Kurniaman, O., \& Zufriady, Z. The effectiveness of teaching materials for graphic organizers in reading in elementary school students. Journal of Educational Sciences, 3(1), 48-62.

Macwan, H. J. (2015). Using visual aids as authentic material in ESL classrooms. Research Journal of English language and literature (RJELAL), 3(1), 91-96.

Mohd-Asraf, R. (2005). English and Islam: A clash of civilizations?. Journal of Language, Identity, and Education, 4(2), 103-118.

Nugroho, Y. S., Nurkamto, J., \& Sulistyowati, H. (2012). Improving Students' vocabulary Mastery Using Flashcards. English Education, 1(1).

Paltridge, B \& Starfield, S. 2013. The handbook of English for Specific Purposes. Oxford.John Wiley \& Sons Inc.

Sholichah, Risti. 2016. Pengembangan Media Card English Vocabulary dalam Pembelajaran Kosa Kata Bahasa Inggris Untuk siswa MI/SD. Retrieved from http://digilib.uin-suka.ac.id/21547/1/11480035_BAB-I_IV-atauV_DAFTAR-PUSTAKA.pdf 